\title{
Challenges to Sustainable Forest Management and Community Livelihoods Sustenance in Cameroon: Evidence from the Southern Bakundu Forest Reserve in Southwest Cameroon
}

\author{
Ewane Basil Ewane ${ }^{1}$, Ewane Bertrand Olome ${ }^{2} \&$ Heon-Ho Lee ${ }^{1}$ \\ ${ }^{1}$ Graduate School of Forest Resources, Yeungnam University, Gyeongsan, Republic of Korea \\ ${ }^{2}$ Park Chung Hee School of Policy and Saemaul, Yeungnam University, Gyeongsan, Republic of Korea \\ Correspondence: Ewane Basil Ewane, Graduate School of Forest Resources, Yeungnam University, 280 \\ Daehak-ro, 712-749, Gyeongsan, Republic of Korea, Tel: 82-53-810-2901. E-mail: ewa4two@ynu.ac.kr
}

\author{
Received: August 10, 2015 Accepted: August 26, 2015 Online Published: November 29, 2015 \\ doi:10.5539/jsd.v8n9p226 URL: http://dx.doi.org/10.5539/jsd.v8n9p226
}

\begin{abstract}
Sustainable forest management in Cameroon is being plagued with many challenges directly related to key issues in the areas of forest law enforcement and governance. This study used questionnaires to examine the major community livelihood activities undertaken in the SBFR causing deforestation and forest degradation and to explore the localized trigger forces, and their implications for sustainable forest management in Cameroon. The authors found that the rated localized forces triggering indiscriminate human activities in the Southern Bakundu Forest Reserve (SBFR) are scarcity of farmland outside the forest reserve land, population growth, poverty and the more fertile nature of the forest reserve land than the limited, overused, and degraded community farming land. In addition, the authors found that forest monitoring activities in the field by forestry officials were plagued with complicity by some corrupt forestry officials, forces of law and order, administration, local management committee leaders, and disgruntled local population in the apprehension of illegal forest exploiters, besides inadequate resources. The strategies to address the above issues have not been prioritized. Based on the results, this paper argues that the governance failure to prioritize more and better investment in modern agriculture, non-wood domestic cooking energy and reliable rural transport systems, amongst others, including building institutional capacity and physical infrastructure compromises sustainable forest management in Cameroon at both the national and local community levels. In this light, a set of holistic and comprehensive strategic programmes are recommended as the way forward to guaranteeing sustainable development in forest management in Cameroon.
\end{abstract}

Keywords: deforestation, forest degradation, forest governance, forest law enforcement, sustainable development.

\section{Introduction}

Cameroon is a major powerhouse of the Congo Basin forest-rich region of the tropical rainforest-rich Central Africa. In Cameroon, forest covers an estimated 20 million hectares (World Resource Institute/Global Forest Watch [WRI/GFW] and Ministry of Forestry and Wildlife [MINFOW], 2011), with annual forest loss estimated at 1\% from 1990-2010 (Food and Agriculture Organization [FAO], 2010). Sustainable forest management encompasses forest law enforcement and governance, involving tackling illegal forest activities, strengthening and reforming forest management institutions, updating and reviewing policy, building legal and institutional frameworks, and increasing capacity to enforce existing laws and policies. Cameroon's robust and comprehensive Forestry Law was enacted in 1994 (Law No. 94/01 of $20^{\text {th }}$ January 1994) and was perceived as the milestone in sustainable forest management. This well-defined national forestry policy is underpinned by a number of legislative and regulatory acts on the management of forests and protected areas (Lambi et al., 2012). The forestry laws are currently being implemented by MINFOW and the Ministry of Environment and Nature Protection (MINEP). The objectives of Cameroon's Forestry Law of 1994 and forest sector policies relating to biodiversity conservation and sustainable development considers the three main principles of sustainable use of forests as put forward by the convention on biological diversity (Tieguhong \& Betti, 2008). In line with the objectives of Cameroon's forest code, the country has made commendable progress in sustainable forest 
management such as increasing the numbers of protected areas, community forests, council forests, and approved management plans for forest management units, as well as promoting multiple-use forest management for income and livelihood sustenance for local communities. In addition, notable advances have been made in creating and updating interactive forest atlases/maps for effective monitoring and enforcement of forest laws and regulations, an automated forestry information management system, a forestry revenue enhancement programme, amongst others (see WRI/GFW and MINFOW, 2005, 2007 \& 2011).

However, sustainable forest management in Cameroon is still overwhelmed with many challenges directly related to forest law enforcement and governance, which are demonstrated by some inherent socio-economic and ecological issues. For example, at the national level, there is still complicity in the implementation of forest laws and regulations, non-retrocession of the official $10 \%$ forest tax revenue to forest dependent communities, duplication and multiplication of institutional functions, institution and land use conflicts, inadequate manpower and financial resources etc. (Oyono, 2005; Amarieri, 2005; Oyono et al., 2005; Cerutti et al., 2008; Alemagi, 2011). Worst still, the culture of lack of accountability and transparency among forestry officials and members of decentralized village management committees in the management of forest resources is compromising the management objectives, and sustainable development of production forests. For example, corruption and embezzlement of forest royalties are common among members of the sub-division and village management committees situated in the East Region of Cameroon (Oyono, et al., 2005; Alemagi \& Kozak, 2010). Furthermore, internal human conflicts between the local population and forestry workers and among the relevant regulatory institutions, coupled with land use conflicts from farmland expansion and other encroachment activities have been generated and increased even after the forestry law was enacted in 1994 and other sectorial programmes introduced (Oyono, 2005; Alemagi, 2011; Lambi et al., 2012). At the community level in Cameroon, some of the challenges to sustainable forest management stemmed from the fact that most forest reserves such as the SBFR were historically and practically created in forest lands already under shifting cultivation and fallow farming by local population with no formal consultation with the local communities concerned. And the affected local population, mostly unskilled, are often ignored and with no alternative sources of livelihood, a scenario which continuously traps them in poverty and misery. This leaves the local population with no option but to continue obtaining their means of livelihood through exploitation activities in sections of permanent forest estates, which they still strongly believe to culturally and biologically be theirs.

Therefore, forest governance institutions and policy at national, regional, and local management units have not brought about the expected positive results of sustainable development so far, in terms of ecological sustenance and improving the socio-economic livelihoods of the population in forest dependent communities. In particular, the problem has been on the most part that of governance crisis, involving the failure to recognize, for example, the necessity to prioritize more and better investment in modern agriculture and non-wood domestic cooking energy, as both sectors are directly impacting forest resources and mainly causing deforestation and forest degradation in Cameroon.

The causes of deforestation in developing countries of Africa, Asia, and Latin America have been well documented (Allen \& Baines, 1985; Agvei, 1997; Geist \& Lambin, 2002; Acheson \& McClosky, 2008; Armenteras et al., 2010). The challenges to sustainable forest management are intertwined with the causes of deforestation and forest degradation in Cameroon. According to MINEP (2013), the direct and indirect causes of deforestation and forest degradation in Cameroon include agriculture, illegal timber exploitation, fuelwood exploitation, industrial logging, mining, population growth, construction of roads, bushfires, and an inheritance system that can lead to land fragmentation and forest cover degradation, in that order. Several studies have also deliberated on the causes of deforestation and forest degradation in Cameroon (e.g. Amariei, 2005; Pye-Smith, 2010; Alemagi \& Kozak, 2010; Epulle et al., 2011; Schwartz et al., 2012). Thus, although the causes of deforestation and forest degradation on a broad national level in Cameroon are well known, the localized factors triggering unauthorized livelihood activities in permanent forests estates at the community level are not well understood or often ignored and needs to be highlighted to aid adequate policy update and review that would guarantee sustainable development in forest management in Cameroon.

The main aim of this study was to examine the major community livelihood activities undertaken in the SBFR and to explore the localized trigger forces and causes of deforestation and forest degradation, and their implications to sustainable forest management in Cameroon. The specific objectives of this study were: (1) to examine the management and monitoring activities implemented by the government in the SBFR, and their implications for sustainable forest management, (2) to highlight the need for governance to be geared towards more and better investment in the non-forestry sectors, particularly agriculture and domestic cooking energy, as they directly impact forest resources at community levels in Cameroon and (3) to recommend some fundamental 
and optimal approaches within and without the forestry sector that should create the enabling environment for effective forest law enforcement and governance and also improve sustainable development in forest management in Cameroon. The recommendations are intended to stimulate further discussion and debate about what holistic and comprehensive measures are needed to guarantee long-term sustainability in forest management in Cameroon. In this regard, the conceptual framework of this study follows the guiding principles of the concept of sustainable forest management.

\section{Method}

\subsection{Study Area}

The case study forest reserve is the SBFR and is among the oldest and most progressively exploited production forests in Cameroon. It extends between latitudes $4^{0} 23^{1} \mathrm{~N}$ and $4^{\circ} 34^{1} \mathrm{~N}$, and longitudes $9^{\circ} 28^{1} \mathrm{E}$. It is one of the 75 forest reserves jointly covering $6 \%$ of the national forest estate and $2 \%$ of the national territory (WRI/GFW \& MINFOW, 2011). It is located adjacent to about 22 small villages (Figure 1 left) in meme division (Figure 1 bottom right) in the Southwest region of Cameroon (Figure 1 top right).

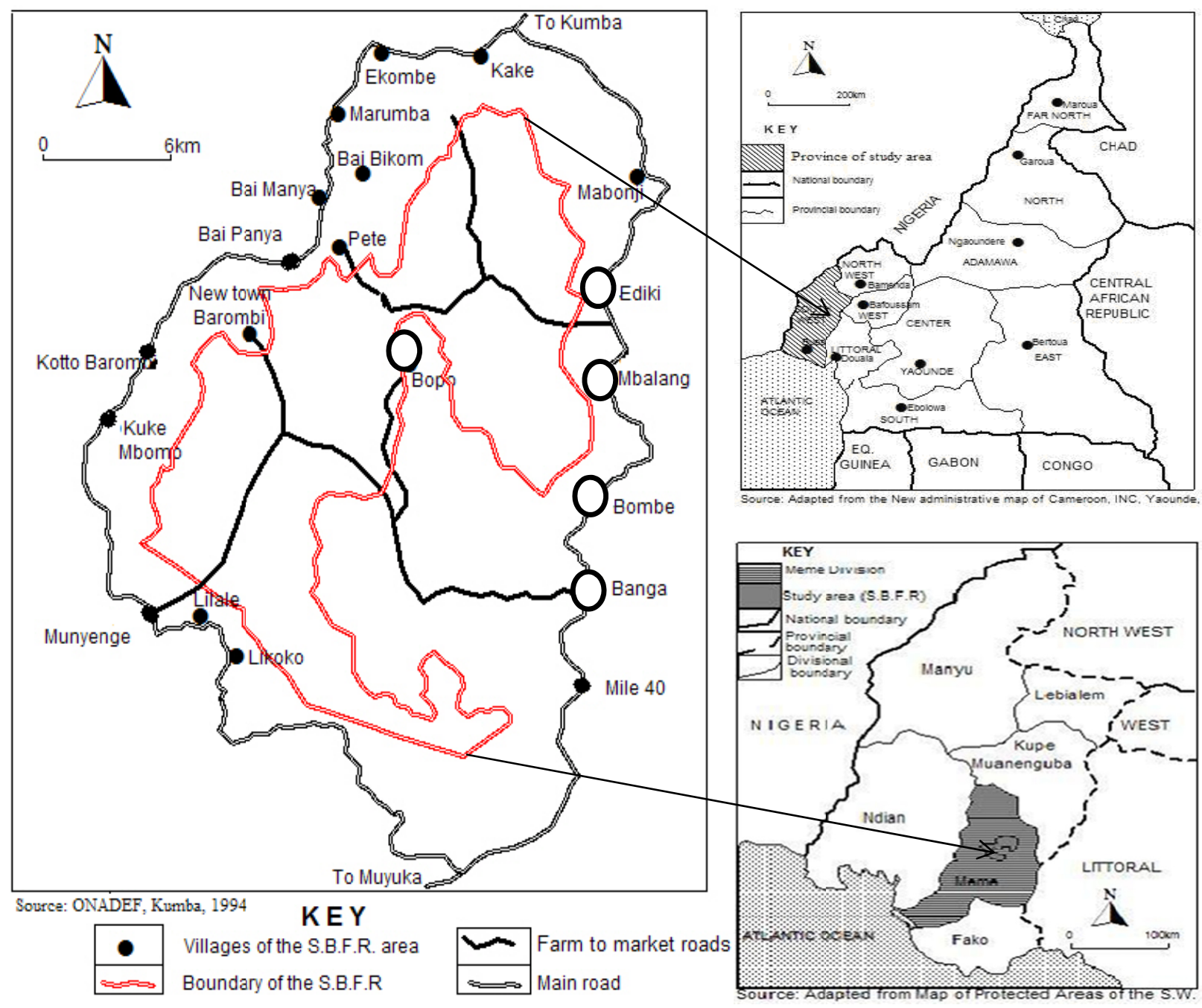

Figure 1. Case study area of the SBFR and the targeted villages (left - circled villages), the regional (stippled area top right) and divisional (shaded area bottom right) location of the SBFR in the Southwest region of Cameroon

The SBFR was originally carved out in 1937 with a surface area of 18,100 hectares as a native administrative forest reserve by the British Colonial Government (Figure 2) during their mandate in Cameroon (Richard, 1963). The Cameroon government officially recognized the creation of the SBFR in 1940 following Decree No. 16 of 1940. It has since then been managed as a production forest reserve with a view to ensuring a sustained 
production of timber and biodiversity conservation.

The evolution of population growth for the individual sample villages of the SBFR area was not available on the website of the National Institute of Statistics/ Institute National de la Statistique. Only the population growth statistics for each of the ten regions and major cities and towns of Cameroon from 1976 to 2013 were reported in the Annual Statistics of Cameroon/Annuaire Statistique du Cameroon of 2013. For instance, the population growth of the Southwest region of Cameroon where the SBFR villages are located has more than doubled within the last 40 years as it increased from 620515 inhabitants in 1976 to 1481433 in 2013 (National Institute of Statistics/Institute National de la Statistique, 2013). This regional data on population growth provides compelling and supportive evidence of the increase in population in the sample villages during that time period.

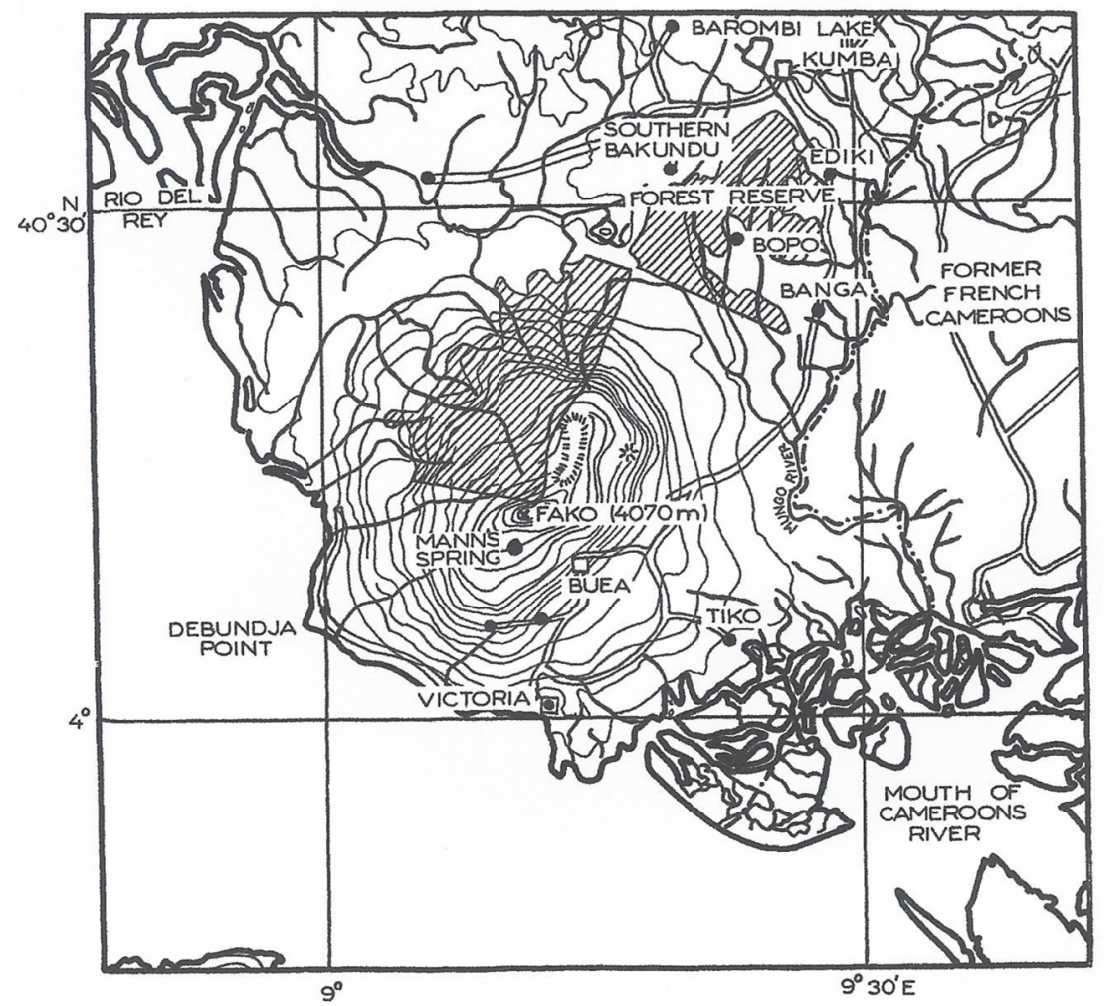

Figure 2. Map of the coastal region of Cameroon showing the SBFR (top stippled area) as carved out in 1937

$($ Scale $=1: 1000$ 000). Source: Extracted and modified from Richards (1963)

\subsection{Case Study Sample Rural Communities}

The communities adjacent to SBFR in the Southwest region of Cameroon that were investigated comprised of five forest dependent villages, namely; Banga, Bombe, Mbalangi, Ediki and Bopo. The villages were selected for sampling based on their accessibility, geographical proximity, historical traits, size, and population. They are among the largest, oldest (see Fig. 2) and most populated villages adjacent to the SBFR based on estimates from field observations and local estimates. Also, the villages are accessible as they are located along the Kumba to Buea highway, a major route to the local markets for exploited NTFPs and illegal timber. In addition, the selected villages were reported to have a long history of exploitation of valuable timber and subsistence farming operations in the SBFR (see Richard, 1963).

\subsection{Sampling and Instrumentation}

The study made use of questionnaires that were administered to 500 adult farmers in the five sample villages (Banga, Bombe, Mbalangi, Ediki and Bopo) on a voluntary and random basis. The target villages have high literacy rates ( $75 \%$ of total national population) as some of the respondents were high school and university graduates who, due to the high unemployment levels in the country, (30\% in 2011) resorted to agriculture for livelihood. Thus, the majority of the respondents read, understood and completed the questionnaires on their own while the illiterate respondents were assisted in the completion of the questionnaires. All the respondents targeted were currently or in the recent past engaged in livelihood activities in the SBFR. The non-response was 
minimized by the large and representative sample size that was completed. Thus, the research was considered exploratory and the results were interpreted accordingly.

The questionnaires to the locals consisted of close-ended questions designed to achieve the objectives of the study. A total of 14 questions were posed to investigate community livelihood activities undertaken in the forest reserve and the driving forces in the progressive long-term "mining" of the forest reserve resources. The respondents were asked to select the major economic activities and the triggers of such indiscriminate exploitation activities in the forest reserve at individual and community levels. In addition, a questionnaire on the main management and monitoring strategies for the SBFR was posed to the staff of the Regional Delegation of Forestry and Wildlife for the Southwest Region in charge of monitoring in the SBFR. The sampling was complemented with exploratory discussions with decentralized forestry officials of the Ministry of Forestry and Wildlife (MINFOW), civil society, traditional elites, local population, and NGO stakeholders working in the SBFR in the South West Region of Cameroon.

\subsection{Data Analysis}

Data from the questionnaires were analyzed on Microsoft excel 2010 to obtain descriptive statistics (means and frequencies) on the various community livelihood activities carried out inside the forest reserve and the driving forces among the five sample villages. Mean responses for the drivers of indiscriminate human activities in the forest reserve were calculated for a 4 point interval scale questions to rank the trigger factors into least significant, significant, very significant and most significant. Inferential statistics were not used because much of the study was exploratory.

\section{Results}

As illustrated in Figure 3, there were significant differences in the intensity of practice of each livelihood activity in the forest reserve. Based on the mean values and percentages for the various livelihood activities, agricultural production, fuelwood exploitation, and NTFPs collection were on average the three major livelihood activities undertaken in the SBFR as indicated by the 500 respondents in the five sample villages (Figure 3). Narrowly, agricultural production and fuelwood exploitation have the most significant causal effect on deforestation and forest degradation in the SBFR (Table 1). The respondents indicated that the spatial extent of the activities were either scattered or widespread, mostly on a permanent basis, on a high to very high exploitation intensity, and with low to high impact on the forest ecosystem (Table 1).

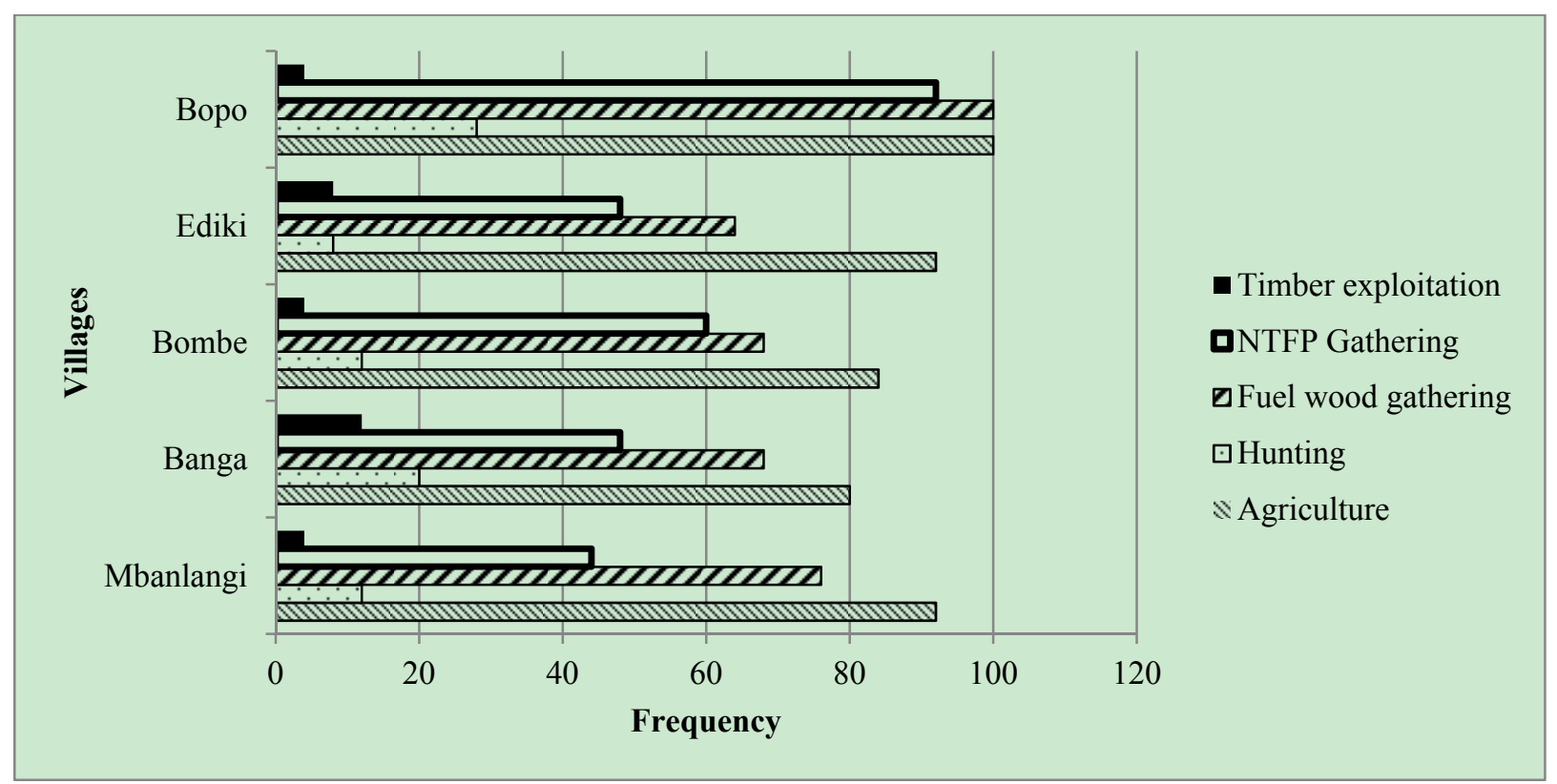

Figure 3. Results of the 100 respondents in each village that was asked to indicate what livelihood activities they are engaged in inside the SBFR 
Table 1. Main livelihood economic activities in the SBFR and their perceived impact on the forest ecosystem

\begin{tabular}{lllll}
\hline Main livelihood economic activity & $\begin{array}{l}\text { Spatial extent of } \\
\text { collection }\end{array}$ & $\begin{array}{l}\text { Impact on the } \\
\text { ecosystem }\end{array}$ & Duration & $\begin{array}{l}\text { Degree } \\
\text { activity }\end{array}$ \\
\hline NTFPs & Widespread & Very low & Permanent & Very high \\
Hunting/poaching & Scattered & Low & Permanent & High \\
Agriculture (cash and food crop) & Widespread & High & Permanent & Very high \\
Timber exploitation & Scattered & High & Permanent & Very high \\
Fuelwood collection & Widespread & High & Permanent & Very high \\
\hline
\end{tabular}

The respondents who indicated to practice agriculture in the forest reserve land were asked to specify the major types of crops which they cultivate, the value in use and to rate the estimated income obtained (Table 2). The respondents indicated that they obtain low to medium income for food crop cultivation, mostly by women, and high to very high income for cash crop cultivation, especially cocoa production, which is a major cash crop for livelihood sustenance in the area, mostly farmed by men.

The animal and wood species mostly exploited by the locals in the sampled communities and their economic value and use is presented in Table 3. The major NTFPs collected in the SBFR are presented in Table 4. Most of the NTFPs such as the edible nuts and leaves are traditionally collected from the forest floor and plucked from live trees, respectively, and the roots, leaves and barks of live trees and shrubs are harvested for medicinal purposes (Table 4).

Table 2. Main food and cash crop mostly cultivated in the SBFR

\begin{tabular}{llll}
\hline Common name & Scientific name & Value and use & Local income obtain rating \\
\hline Food crop & & & \\
\hline Plantain & Plantago majus & Food and income & Medium \\
Cassava & Manihot spp. & Food and income & Medium \\
Yams & Dioscorea spp. & Food and income & Medium \\
Cocoyams & Zanthosoma spp. & Food and income & Medium \\
Egusi & Citrallus colocynthis & Food and income & Low - medium \\
Maize & Zea mays & Food and income & Low \\
Banana & Musa spp. & Food and income & Low - medium \\
Okro & Gardenia jasminoides & Food and income & Very low \\
\hline Cash crop & & & \\
\hline Cocoa & Theobroma cacao & Income & High - very high \\
Rubber & Hevea brasiliensis & Income & High - very high \\
Oil palm & Elaeis guineensis & Income & High - very high \\
\hline
\end{tabular}

Table 3. Main animal and wood species for timber exploited in the SBFR

\begin{tabular}{lll}
\hline Common name & Scientific name & Purpose and use \\
\hline Animal species & & \\
\hline Cave rat (rat mole) & Heteropsomys insulans & Mostly for food \\
Giant squirrel & Ratufa centralis & For food \\
Monkey & Cercaicebus spp. & Food and income \\
Snakes & Serpentis spp. & For food \\
Porcupine & Atherurus africanus & Food and income \\
African civet & Civettictis civetta & Food and income \\
\hline
\end{tabular}




\begin{tabular}{lll}
\hline Wood species & & \\
\hline Bobinga & Guibourtia tessmannii & Income and construction/furniture \\
Bilinga & Naudeo publeguirii & Income and construction/furniture \\
Sipo & Entandrophragma utile & Income and construction/furniture \\
Doussie & Afzelia pachyloba & Income and construction/furniture \\
Sapelli & Entandophragma cylindricum & Income and construction/furniture \\
Debema & Piptadeniastrum africanum & Income and construction/furniture \\
Frake & Terminalia superba & Income and construction/furniture \\
Zebranum & Microberlinia bisculaita & Income and construction/furniture \\
Bassam mahogany & Khaya ivorensis & Income and construction/furniture \\
\hline
\end{tabular}

Results from the five sample villages revealed that the driving forces behind the indiscriminate agricultural and illegal forest activities inside the forest reserve land were mainly: (1) increased scarcity of farming land outside the forest reserve, (2) increased population, (3) poverty and (4) the fertile nature of the forest reserve land in comparison to the community farming land, in that order (Figure 4). During the field data collection, the villagers lamented on the issue of increased scarcity of farming land outside the forest reserve which they attributed to population growth.

Table 4. Main non-timber forest products exploited in the SBFR

\begin{tabular}{lll}
\hline Local name & Scientific name & Purpose and part used \\
\hline Bush mango & Irvingia gabonensis & Food-fruit and nut \\
Bush Onion & Afrosyrase lepidophyllus & Food-Leaf, bark and seed \\
Noisette & Coula edulis & Medicinal-bark; Food-nut \\
Kola & Kola accuminata, K. caricifolia K. garcinia and & Medicinal and Food-Fruit \\
& K. nitida & \\
Milk stick & Euphorbia tirucalli & Medicinal-all parts \\
Feuilles & Afromamum hanburyl and A. melequeta & Medicinal-leaf; Food-seed \\
Njinja & Zingiber officinalis & Food-root \\
Quinine stick & Cinchona & Medicinal-bark \\
Njansang & Ricinedron heudolotti & Food-nut \\
Eru & Gnetum africana & Food-leaf \\
Cam wood & Baphia nitida & Medicinal-bark \\
Maobi fruits & Baillonnela tixisperma & Food-fruit \\
Padouk & Pterocarpus soyauxii & Medicinal-bark; Food-leaf \\
Bush pepper & Piper guineensis & Food-fruit (dried seeds) \\
Cures dents & Garcinia manu & Medicinal-leaf and fruit \\
Young Moambe & Enantia chlorant & Medicinal-bark and leaf \\
Emien & Alstonia boonei & Medicinal-bark and root \\
Mosusu & Terminalia sericia & Medicinal-bark and root \\
Okan & Cylicodiscus gabunensis & Medicinal-bark and leaf \\
\hline
\end{tabular}




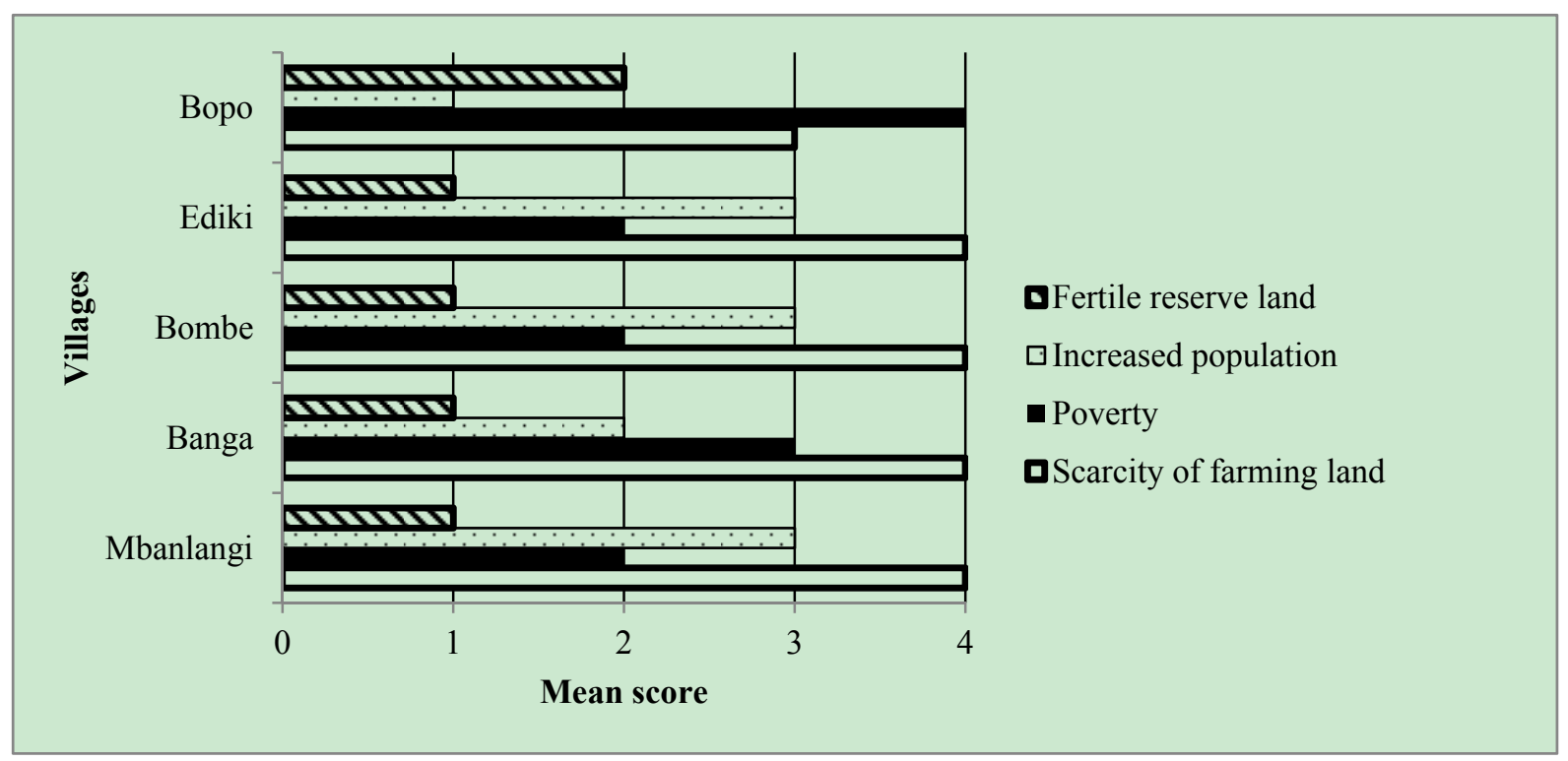

Figure 4. Ranking of the triggers of the indiscriminate community exploitation and degradation of the SBFR based on the number of times each aspect was ticked ( $1=$ Least significant, $2=$ significant, $3=$ very significant, $4=$ most significant)

The main management and monitoring activities carried out by the Delegation of Forestry and Wildlife workers in the SBFR over the last decade is presented in Table 5. Clearing and routine boundary demarcation, research, species identification, inventory and watershed protection activities were not part of the main routine activities undertaken by the decentralized forest management institutions in charge of monitoring and management of the SBFR over the last decade (Table 5). The number of illegal forest exploiters arrested from 2010 to 2014 as illustrated in Figure 5 and reveals that the number of apprehended cases dropped from 2010 to 2013 but showed an increase in 2014.

Table 5. Management activities carried out by the Delegation of Forestry and Wildlife workers in the SBFR from 2010 to 2014

\begin{tabular}{|c|c|}
\hline Major Activities & Management strategies and frequency \\
\hline Policing and guarding of the forest reserve & $\begin{array}{l}\text { Quarterly patrols by the Regional Delegation of Forestry and } \\
\text { Wildlife Buea. } \\
\text { Bi-monthly patrols by the Divisional Delegation of Forestry and } \\
\text { Wildlife for Meme, Kumba. } \\
\text { Weekly patrols by the Forestry and Wildlife control post of Banga } \\
\text { Bakundu. }\end{array}$ \\
\hline $\begin{array}{l}\text { Routine boundary demarcation and } \\
\text { clearing }\end{array}$ & Not applicable \\
\hline $\begin{array}{l}\text { Research and species identification and } \\
\text { inventory }\end{array}$ & Not applicable \\
\hline Regeneration/restoration of degraded areas & Annually (tree planting) \\
\hline Watershed protection activities & Not applicable \\
\hline Other job specification activities & Farm encroachment survey conducted annually \\
\hline
\end{tabular}




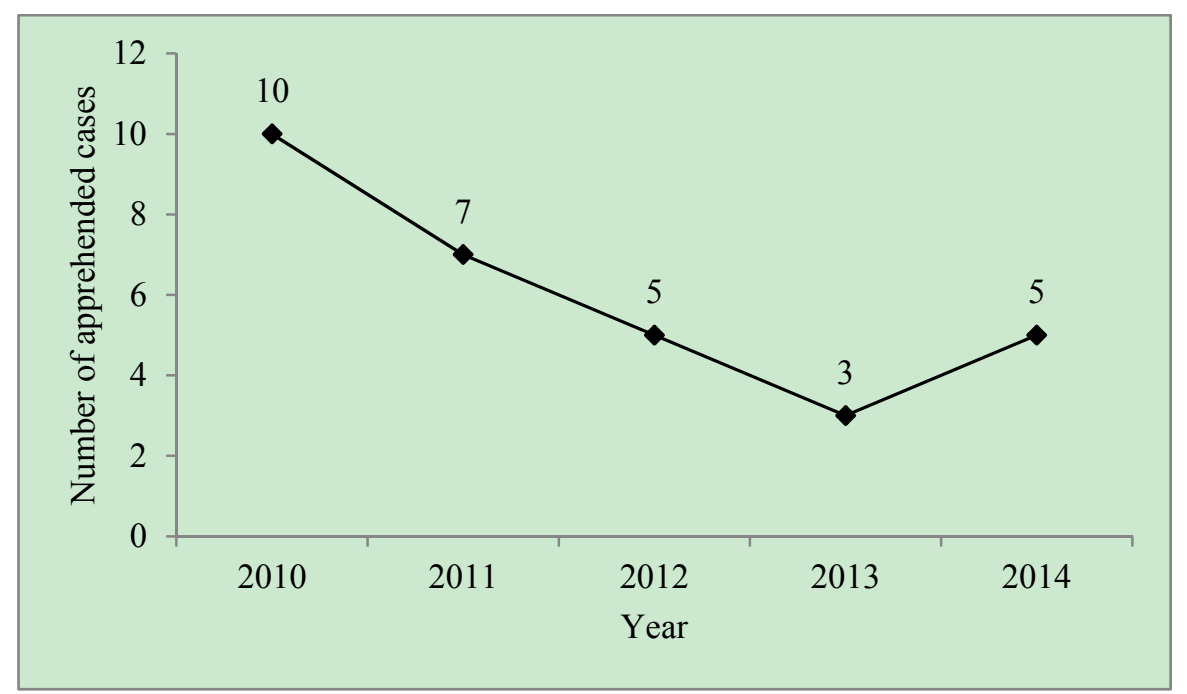

Figure 5. Cases of illegal forest exploitation activities apprehended annually in the SBFR from 2010 to 2014

\section{Discussion}

\subsection{Community Exploitation Activities in the SBFR: Triggers and Causes}

Cameroon's forests are located in enclaved rural areas where the population is extremely poor and solely dependent on agriculture, fuelwood, wood products, NTFPs and hunting for local livelihood sustenance. Thus, ending indiscriminate deforestation and forest degradation cannot be guaranteed without increased and better investment in modern agriculture inputs, non-wood domestic energy and rural development. The study found that community agricultural production expansion, fuelwood exploitation and illegal timber exploitation are the main local livelihood economic activities that directly cause deforestation and forest degradation in the SBFR. The scarcity of farming land, increased population, poverty and fertile reserve land, in that order, were rated as the main factors triggering the indiscriminate local livelihood activities in the SBFR. Richard (1963) reported that the area carved out as the SBFR was highly modified and showed evidence of early human occupation in the form of shifting cultivation and fallow farming, detected by the presence of fragments of pottery and charcoal in the soil profile of sample plots, and small-scale exploitation of timber for planks in-situ. Although the extent of human interference was certainly less severe at the time the forest reserve was created because the population was low, the increased population growth in the villages has caused scarcity of cultivable land, jointly triggering the expansion of permanent crop production, unsustainable fuelwood collection and illegal timber exploitation in the forest reserve. This result is justified by the result of a previous study which estimated that more than $10.35 \%$ (952 ha.) of the SBFR was covered by plantations of cocoa, rubber, and oil palm and agroforestry estates (Southern Bakundu Project, 1994). This further demonstrates the scenario of unabated expansion of farming and other livelihood activities in the forest reserve triggered by the scarcity of farming land outside the forest reserve land, increased population growth in the villages adjacent to the SBFR, poverty and the more fertile forest reserve land than community farming land.

The results of this study are also in conformity with that of several previous studies. For example, Epulle et al. (2011) found that population growth and agricultural land expansion and development for food and permanent cash crop production are the two most dominant triggers and causes of deforestation in Cameroon. Other studies have also reported that increase in population and expansion of agricultural land is associated with deforestation and forest degradation in Africa and Asia (Allen \& Barnes, 1985; Acheson \& McClosky, 2008; Mmom \& Mbee, 2013). Similarly, about $96 \%$ of deforestation in Africa, Asia and Latin America is caused by agricultural land expansion (Geist \& Lambin, 2002). Furthermore, FAO (2004) reported that over $80 \%$ of the local communities in Cameroon depend on natural and forest resources for their farming activities and close to $80 \%$ of rural households in Cameroon practice slash and burn subsistence farming (Cerutti et al., 2010). Therefore, the usual trend has been to abandon the degraded forest-farming areas when the soil fertility decreases and to encroach into more fertile permanent forest lands. The SBFR can best be described as a continuum of permanent crop plantations, especially of cocoa, with planted food crops scattered in the understorey of remnants of heavily fragmented forest areas for local livelihood sustenance. The effect of fuelwood collection is in line with the data provided by MINEP (2013), which stated that more than $90 \%$ of households in rural areas of Cameroon still use 
fuelwood as a primary source of domestic cooking energy and less than $40 \%$ of the population in urban areas have access to modern domestic energy services such as cooking gas.

It is widely understood that as population increases, the need for more land for settlement, agriculture, and domestic energy increases, while ecosystem degradation also increases. The annual population growth rate of Cameroon is estimated at 2.6\% in 2013 (National Institute of Statistic/Institute National de la Statistique, 2013) but data on population growth for the individual sample villages was not available, except that for the regions and major cities and towns. For instance, data on population growth for the Southwest region of Cameroon where the sample villages are located has more than doubled within the last 40 years as it increased from 620 515 inhabitants in 1976 to 1481433 in 2013 (National Institute of Statistics/Institute National de la Statistique, 2013). This regional data on population growth provides compelling and supportive evidence of the increase in population in the sample villages during that period of time. The respondents indicated that population increase in the villages adjacent to the forest reserve has caused increased scarcity of farming land outside the forest reserve, forcing exploitation in the more fertile forest reserve land.

The collection of NTFPs and traditional hunting in the forest reserve was also found to be major local livelihood activities undertaken in the SBFR, and both have low impact on the forest ecosystem. These two activities are authorized by section 25(2) of the 1994 Forestry Law on local population customary rights in states forest because their impact on the forest ecosystem is low. This view is supported by FAO (2014), who reaffirmed that the collection of NTFPs and traditional hunting are authorized livelihood activities contributing to income, food security, and nutrition for households in rural communities of the Congo Basin.

Illegal timber exploitation by sawyers for plank in-situ is another major economic activity undertaken in the SBFR. Although the frequency in terms of the number of individuals involved in the activity was indicated to be small (for fear of victimization or seizure of available or potential illegal harvested timber), its effect on deforestation and forest degradation is as high as the income generated from the activity by those involved. Previous personal field observation and results on national studies provide strong evidence to this study's result. This is true because large scale illegal timber exploitation has been reported as a major challenge to sustainable forest management in Cameroon and is fueled by the flourishing local and regional market in the informal timber sector (Amariei, 2005; Cerutti et al., 2008; Alemagi \& Kozak, 2010). In addition, Pye-Smith (2010) estimated that the volume of timber entering the domestic market in Cameroon is roughly equivalent to that of the export market, and nearly $75 \%$ of the wood supplying the former comes through the informal sector. Valuable tree species such as iroko (Chlorophora excelsa), Bossé (Guarea thompsonii, G. cedrata) and Eteng (Pycnanthus angolensis) Ayous (Triplochiton scleroxylon), zingana (Microberlinia bisulcata), Kapok (Ceiba pentandra), Moabi (Baillonella toxisperma), Azobe (Lophira alata), Movingui (Distemonanthus benthamianus) etc., which were reported by Richards (1963) to be enormous in the SBFR are currently either extinct or critically threatened to extinction due to progressive long term formal over exploitation, excessive illegal timber exploitation, and extensive forest clearance for agriculture.

Poverty was also found to be a major trigger factor to the increased deforestation and forest degradation in the SBFR. There is a vicious cycle between poverty and deforestation and forest degradation in local forest dependent communities in most sub-Saharan African countries. This result is in line with that of Mmom and Mbee (2013) who reported that poverty is one of the factors driving the depletion of forest resources in the Gele-Gele forest reserve in Edo state, Nigeria. Furthermore, the relatively more fertile forest reserve land in comparison to community farming land was also an important trigger factor to the increased deforestation and forest degradation in the SBFR as found in this study. The epochal traits of shifting cultivation and fallow farming systems in the SBFR even before increased population growth and scarcity of farming land in the sample villages became major trigger factors to the increased deforestation provides persuasive evidence of the more fertile nature of the forest reserve land in comparison to the community farming land. This result is in conformity with an earlier study by Richard (1963), which reported that due to the relatively more fertile soil in the SBFR in relation to around the adjacent villages, agro industrialists, migrant farmers, and indigenous population groups mainly increase food production by expanding agricultural cultivation inside the forest reserve. This situation poses increasing threat to the sustainability of the SBFR because as the population increases in the adjacent villages, the already converted agricultural land inside the forest reserve will further become inadequate to support the growing population. This will trigger even more deforestation of the forest reserve land in search for more fertile arable land, fuelwood and wood products for income and livelihood sustenance.

\subsection{Forest Management and Monitoring Activities in the SBFR}

The management of forests in Cameroon is the duty of MINFOW and MINEP and their decentralized agencies at 
regional and divisional levels. The study found that the SBFR is not managed under any management plan or zoning plan and the management strategies involved quarterly patrols by the Southwest Regional Delegation of Forestry and Wildlife located in Buea, bi-monthly patrols by the Divisional Delegation of Forestry and Wildlife for Meme located in Kumba, and weekly patrols by the Forestry and Wildlife control post located in the Banga Bakundu village. The frequency of the monitoring activities was reflected in the small number of cases of illegal forest exploitation activities apprehended each year from 2010 to 2014 in the SBFR despite the widespread encroachment of permanent agricultural activities and illegal timber exploitation taking place in the forest reserve. The surprisingly small number of apprehended illegal exploitation activities in the SBFR was attributed to the widespread complicity of forestry officials, forces of law and order, local administration at the sub-divisions, traditional elites, members of decentralized village management committees and local population in the SBFR area. Inaccessibility of some parts of the forest reserve to guards and impossibility of night patrols to track overnight illegal timber sawyers also limits the number of apprehended cases. Corruption and embezzlement of forest royalties meant for local communities by forestry sector officials (Oyono, 2005; Alemagi, 2011) has created bitterness among decentralized village management committees and their local populations, which partly fuels complicity in their cooperation with forestry officials in the apprehension of illegal forest exploiters.

In addition, this study found that the traditional boundaries of the forest reserve demarcated in 1939 by the British colonial administration has never been re-demarcated to officially provide more farmland to the local communities whose increasing population has caused acute scarcity of cultivable land to sustain livelihood. The government's inaction to re-demarcate the forest reserve land to address the long standing problem of scarcity of farmland with increasing population only fuels illegal exploitation activities inside the forest reserve. This has led to increased conflict between local villagers and government agencies' staff charged with the management of the SBFR. Richard (1963) earlier reported that the management of the SBFR has long shown conflicting priorities between the government and conservation officials, agro-industrial interests, migrant farmers and indigenous population groups. Recent studies have affirmed that the law and the institutions of forest management have not brought the expected positive results of sustainable development, rather have generated and increased internal human conflicts between local population and forestry workers, and land use conflicts from farmland expansion and other illegal activities (Oyono, 2005; Lambi et al., 2012).

Therefore, this study argued that the main and direct causes of deforestation and forest degradation in Cameroon, which includes agriculture, illegal timber exploitation, and fuelwood exploitation cannot be reversed solely by relying on forest law enforcement and governance under present livelihood conditions of rudimentary rainfed agriculture, food insecurity and poor nutrition, poverty, and nationwide dependence on wood energy for domestic cooking. Only when more and better investments in modern agriculture inputs, food security, nutrition and domestic non-wood cooking energy are given practical recognition would sustainable development in forest management be achieved in Cameroon. More and better investment in modern agriculture technology, for example, provides an option to increase food production without having to significantly and indiscriminately expand agricultural land.

\section{Recommendations and Perspectives}

The recommendations discussed below emphasize the need to guarantee long-term sustainability in forests and protected area management in Cameroon through holistic national policy reforms to forest management and governance. Policy makers must consider the following recommendations to guarantee the hard fought progress and advances in sustainable forest management in Cameroon.

1. The results of this study clearly point to the urgent need for the government of Cameroon to embrace and increase investment levels in the broad use of technology in agriculture (fertilizers, improved seeds, equipment, irrigated water etc.) and non-wood domestic cooking energy, including building institutional capacity and physical infrastructure as these activities are impacting forest resources the most.

2. The government should provide reliable rural transport systems connecting the remote forest communities (where the forests and protected areas are predominantly located) to urban centers. This will make field monitoring and control less of a nightmare for forest extension workers and should reinstate the long destroyed umbilical cord that is supposed to connect these forest workers with the local populations living adjacent to the permanent forests estates. These invariably will promote participatory forestry and community-based forest management. Reliable transport systems connecting rural and urban markets will also boost farm income and create vibrant villages.

3. The Cameroon government must train forest technicians in emerging trends of nature conservation and 
multiple-use forest management (including short-term income, ecotourism, safeguarding multiple ecosystem services and climate change education). At the moment, there are only two forest technical training schools in Cameroon; namely, the National Forestry School in the town of Mbalmayo (center region) and the National Wildlife Training School/École pour la Formation de Spécialistes de la Faune in Garoua (north region) offering accredited diplomas in forestry. And there is only one higher institution (University of Dschang) that offers a degree programme in forestry. Furthermore, data on forest education relating to enrollment and graduation of students in forest related education and on forest research professionals working in publicly funded forest research centres was unavailable for Cameroon (FAO, 2010). In this light, there is pressing need for the government to create and equip specialized forest vocational/technical education, higher forest research institutes and teaching institutions to train forest technicians and engineers, and maintain records publicly from which future forestry education needs can be based to meet future forestry needs. These national institutions will increase the capacity of forest extension workers to enforce the existing forestry laws and policies. The trained local foresters will improve on national data collection on forest management and monitoring and provide the foundation for improved planning, decision-making, and increase public awareness on sustainable forest management in Cameroon.

4. Lastly, there is pressing need for a nationwide strong leadership and relentless campaigns to promote national best interests and sustainable development in forest management as opposed to the culturally embedded self-interest in forest management at all levels. This is because governing the state forests through the freedom of the conscience of forestry officials encourages complicity and self-interest in forest management and compromises long-term national and global best interests for sustainable forest management by degrading forest resources. Strong leadership at all levels of society will ensure a culture of discipline, accountability, and transparency in forest governance and promote sustainable development in forest management in Cameroon.

\section{Conclusions}

The study aimed to mainly examine and explore the localized causes and triggers of deforestation and forest degradation in the SBFR and the monitoring activities implemented by the forestry agencies, and their combined implications for sustainable forest management in Cameroon. The study found that agricultural expansion activities, fuelwood collection and illegal timber exploitation were by far the most degrading community livelihood activities undertaken in the SBFR as opposed to NTFPs collection and traditional hunting activities. Unlike the well documented population growth and poverty trigger factors, increased scarcity of farmlands within the community land and the more fertile nature of forest reserve land compared to the over-cultivated and depleted community farming land were found to be the rated localized and more subtle trigger factors of deforestation and forest degradation in the SBFR. This is sadly the situation in other permanent forest estates in Cameroon with similar background characteristics of epochal human occupation and rapid growing population in adjacent villages though often ignored. The well-intended forest reserve monitoring activities involving quarterly, bi-monthly, and weekly patrols by forestry officials were hampered by complicity of some corrupt forestry officials, forces of law and order and administration, local forest management committee leaders and the disgruntled local population.

Therefore, the results provide persuasive evidence that forest law enforcement and governance per-say cannot guarantee sustainable development in forest management in Cameroon under present conditions of rudimentary rainfed agriculture, nationwide dependence on fuelwood for domestic cooking, poverty, and deplorable seasonal roads in rural communities adjacent to permanent forest estates. Based on the results, the study argued that more and better investment in modern agriculture, non-wood domestic cooking energy, reliable rural transport networks connecting urban centers, forest education and research, and strong leadership, including strengthening institutional capacity and physical infrastructure will improve on local livelihood and reduce local community-induced deforestation and forest degradation in Cameroon. Considering the progress already made in advancing sustainable development in forest management in Cameroon, the implementation of the above mentioned recommendations by the government will undoubtedly go a long way to promote sustainable development in forest management and national forest social responsibility at all levels and by all stakeholders in Cameroon.

\section{Acknowledgements}

The authors would like to thank Ettagbor Hans Enukwa, a staff of the Southwest Regional Delegation of Forestry and Wildlife, traditional heads in the forest dependent villages targeted in the study area and heads of civil society in forest dependent communities in Cameroon for providing insights about forest management in their communities. The authors also thank Ewoh Linda Ejob for her assistance during field data collection and 
manuscript preparation.

\section{References}

Acheson, J. M., \& McClosky, J. (2008). Causes of deforestation: The Maine case. Human Ecology, 36, 909-922. http://dx.doi.org/10.1007/s10745-008-9204-3

Agvei, Y. (1997). Deforestation in Sub-Saharan Africa. African technology forum. The information source for the Science and Technology in Africa, 8(1). Retrieved from $\mathrm{http} / / / \mathrm{web} . \mathrm{mit} . \mathrm{edu} / \mathrm{africantech} / \mathrm{www} / \mathrm{articles} /$ Deforestation.htm

Alemagi, D. (2011). Sustainable development in Cameroon's forestry sector: Progress, challenges, and strategies for improvement. African Journal of Environmental Science and Technology, 5(2), 65-72. http://www.academicjournals.org/AJEST

Alemagi, D., \& Kozak, R. A. (2010). Illegal logging in Cameroon: Causes and the path forward. Forest Policy Economics, 12(8), 554-561. http:// doi:10.1016/j.forpol.2010.07.008

Allen, J. C., \& Barnes, D. F. (1985). The causes of deforestation in developing countries. Annals of the Association of American Geographers, 75, 163-184. http://dx.doi.org/10.1111/j.1467-8306.1985.tb00079.x

Ameriei, L. (2005). Legal compliance in the forest sector: A case study of Cameroon. Final report, FAO, Rome. Retrieved from http://www.fao.org/forestry/12937-3-0.pdf

Armenteras, D., Rodriguez, N., Retana, J., \& Morales, M. (2010). Understanding deforestation in montane and lowland forest of the Colombian Andes. Regional Environmental. Change. http://dx.doi.org/10.1007/s10113-010-0200-y

Cerutti, P. O., Lescuyer, G., Assembe-Mvondo, S., \& Tacconi, L. (2010). The challenges of redistributing forest-related monetary benefits to local communities: a decade of logging area fees in Cameroon. Centre for International Forestry Research (CIFOR), Bogor, Indonesia.

Cerutti, P. O., Nasi, R., \& Taconi, L. (2008) Sustainable forest management in Cameroon needs more than approved forest management plans. Ecology and Society, 13(2), 36-48. Retrieved from http://www.ecologyandsociety.org/vol13/iss2/art36/

Epulle, T. E., Peng, C., Lepage, L., \& Chen, Z. (2011). Forest Loss Triggers in Cameroon: A Quantitative Assessment Using Multiple Linear Regression Approach. Journal of Geography and Geology, 3(1), 30-41. http://doi:10.5539/jgg.v3n1p30

FAO. (2004). Human energy requirements: Report of a Joint FAO/WHO/UNU Expert Consultation Rome, 17-24 October 2001. Retrieved from http://www.fao.org/3/a-y5686e.pdf

FAO. (2010). Forest Resource Assessment. FAO Forestry Paper No. 163, FAO, Rome. Retrieved from http://www.fao.org/docrep/013/i1757e/i1757e.pdf

FAO. (2014). Enhancing the contribution of non-wood forest products to food security in Central Africa. Retrieved from http://www.fao.org/forestry/42198-0b308c1736ef8bc3b85bf3852bdd771e8.pdf

Geist, H. J., \& Lambin, E. F. (2002). Proximate causes and underlying driving forces of tropical deforestation. Bio Science, 52, 143-150. http:// doi:10.1641/0006-3568(2002)052[0143:PCAUDF]2.0.CO;2

Lambi, C. M., Kimengsi, J. N, Kometa, C. G., \& Tata, E. S. (2012). The management and challenges of protected areas and the sustenance of local livelihoods in Cameroon. Environment and Natural Resources Research, 2(3), 10-18. http://dx.doi.org/10.5539/enrr.v2n3p10

MINEP. (2013). Document submitted to the "Readiness Preparation Proposal (R-PP)" of the "Forest Carbon Partnership Facility (FCPF) of the United Nations Collaborative Programme on Reducing Emissions from Deforestation and Forest Degradation in Developing Countries. Retrieved from https://www.forestcarbonpartnership.org/sites/forestcarbonpartnership.org/files/Documents/PDF/Feb2013/C ameroon\%20final\%20R-PP-English-January\%202013.pdf

Mmom, P. C., \& Mbee, M. D. (2013). Population pressure and forest resources depletion in Gele-Gele forest reserve of Edo State, Nigeria. International Journal of Physical and Human Geography, 1(3), 31-42. $\mathrm{http}: / /$ www.eajournals.org

National Institute of Statistics/Institute National de la Statistique - Annual Statistics of Cameroon/Annuaire Statistique du Cameroun. (2013). Retrieved from http://www.stat.cm/downloads/annuaire/2013/Annuaire_statistique_2013.pdf 
Oyono, P. R. (2005). Profiling local-level outcomes of environmental decentralizations: The case of Cameroon's forests in the Congo Basin. Journal of Environment and Development, 14(2), 1-21.

Oyono, P. R., Kouna, C., \& Mala, W. (2005). Benefits of forests in Cameroon. Global structure, issues involving access and decision-making hiccoughs. Forest Policy Economics, 7(3), 357-368. http://doi:10.1016/S1389-9341(03)00072-8

Pye-Smith, C. (2010). Cameroon's hidden harvest. Bogor, Indonesia, Center for International Forestry Research (CIFOR), 28p. Retrieved from http://www.cifor.org/nc/online-library/browse/view-publication/publication/3315.html

Richards P. W. (1963). Ecological notes of West African vegetation: II. Lowland forest of the Southern Bakundu Forest Reserve. Journal of Ecology, 51(1), 123-149. Retrieved from http://www.jstor.org/stable/2257510

Schwartz, B., Hoyle, D., \& Nguiffo, S. (2012). Emerging trends in land use conflicts in Cameroon: overlapping natural resource permits threaten protected areas and foreign direct investment. An ad hoc working paper: Joint WWF, REFUFA \& CED Publications. Retrieved from http://awsassets.panda.org/downloads/cameroonminingenglish.pdf

Southern Bakundu Project. (1994). Plan d'amenagement de la Reserve de Sud Bakundu-Kumba: OBIT-ONADEF.

Tieguhong, J. C., \& Betti, J. L. (2008). Forest and protected area management in Cameroon. ITTO Tropical Forest $\quad$ Update, $18(1), \quad 6-9 . \quad$ Retrieved from http://www.itto.or.jp/live/Live_Server/4075/tfu.2008.01(06-09).e.pdf. ISSN: 1022-5439

WRI/GFW, \& MINEF. (2005). Interactive Forestry Atlas of Cameroon: Version 1.0. Washington, DC: World Resources Institute. Retrieved from http://www.wri.org/sites/default/files/pdf/cameroon_atlas_english.pdf

WRI/GFW, \& MINFOF (2011). Interactive Forestry Atlas of Cameroon: Version 3.0. Washington, DC: World Resources Institute. Retrieved from http://pdf.wri.org/interactive_forest_atlas_of_cameroon_version_3_0.pdf

WRI/GFW, \& MINFOF. (2007). Interactive Forestry Atlas of Cameroon: Version 2.0. Washington, DC: World Resources Institute. Retrieved from http://www.wri.org/sites/default/files/pdf/gfw_cameroon_atlas_v2_english.pdf

\section{Copyrights}

Copyright for this article is retained by the author(s), with first publication rights granted to the journal.

This is an open-access article distributed under the terms and conditions of the Creative Commons Attribution license (http://creativecommons.org/licenses/by/3.0/). 